\title{
Amblyomma nodosum Neumann, 1889 on collared anteaters (Tamandua tetradactyla) from the Andean region of Colombia
}

\author{
Amblyomma nodosum Neumann, 1889 em Tamanduá-mirim \\ (Tamandua tetradactyla) da Região Andina Colombiana

\begin{abstract}
Laura Natalia Robayo-Sánchez ${ }^{10}$; Alejandro Ramírez-Hernández'1,2 (1); Jesús Alfredo Cortés-Vecino1* (1)
'Grupo Parasitología Veterinaria, Departamento de Salud Animal, Facultad de Medicina Veterinaria y de Zootencia, Universidad Nacional de Colombia, Bogotá D.C., Colombia

${ }^{2}$ Rickettsial and Ehrlichial Diseases Research, Department of Pathology, University of Texas Medical Branch. Galveston, TX
\end{abstract} \\ United States of America
}

\begin{abstract}
How to cite: Robayo-Sánchez LN, Ramírez-Hernández A, Cortés-Vecino JA. Amblyomma nodosum Neumann, 1889 on collared anteaters (Tamandua tetradactyla) from the Andean region of Colombia. Braz J Vet Parasitol 2020; 29(4): e007120. https://doi. org/10.1590/S1984-29612020071
\end{abstract}

\begin{abstract}
Amblyomma nodosum is a Neotropical tick species distributed from Mexico to Argentina, with adult individuals infesting different mammal species, including anteaters (Pilosa: Myrmecophagidae). Few reports in Colombia have recorded this species in departments such as Meta, Tolima and Valle del Cauca. In this paper we describe this species using taxonomic, morphometric and molecular methods after collecting individuals parasitizing collared anteaters (Tamandua tetradactyla) in the departments of Cundinamarca and Tolima. Adult specimens were identified based on current taxonomic keys and different morphometric variables were documented in nonengorged individuals. Also, DNA was extracted for PCR amplification and sequencing of $16 \mathrm{~S} \mathrm{rDNA}, \mathrm{CO}$ and ITS2 genes. Phylogenetic trees were built. One hundred and thirty-four adult ticks were collected and identified as Amblyomma nodosum, based on morphological, morphometric, molecular and phylogenetic analyses. This is the first study to report the presence of this tick species in the department of Cundinamarca, using multiple identification approaches, thus expanding its geographical records in Colombia.
\end{abstract}

Keywords: Acarology, ticks, Ixodidae, taxonomy, phylogeny, Myrmecophagidae.

\section{Resumo}

Amblyomma nodosum é uma espécie de carrapato Neotropical distribuída do México à Argentina com indivíduos adultos, infestando diversas espécies de mamíferos, incluindo tamanduás (Pilosa: Myrmecophagidae). Na Colômbia, limitados relatos têm registrado essa espécie em alguns departamentos como Meta, Tolima e Valle del Cauca. Neste trabalho, espécimes foram identificados por meio de métodos taxonômicos, morfométricos e moleculares após serem coletados parasitando indivíduos de tamanduá-mirim (Tamandua tetradactyla) dos departamentos de Cundinamarca e Tolima. Espécimes adultos foram identificados por meio de chaves taxonômicas e diversas variáveis morfométricas foram registradas em indivíduos não ingurgitados. Além disso, o DNA foi extraído para amplificação pela PCR e por sequenciamento dos genes $16 \mathrm{~S}$ rDNA, COI e ITS2. Árvores filogenéticas foram construídas. No total, 134 carrapatos adultos foram coletados e identificados como Amblyomma nodosum por meio de análises morfológicas, morfométricas, moleculares e de filogenia. Este é o primeiro estudo que relata, por meio de múltiplas ferramentas de identificação, esta espécie no departamento de Cundinamarca ampliando assim seus registros geográficos na Colômbia.

Palavras-chave: Acarologia, carrapatos, Ixodidae, taxonomia, filogenia, Myrmecophagidae. 


\section{Introduction}

Amblyomma nodosum Neumann 1889 is a Neotropical tick species broadly distributed from Mexico to Argentina (Nava et al., 2017). Adult stages infest mainly anteaters (Pilosa: Myrmecophagidae) but also other mammals of the orders Carnivora (Canidae), Cingulata (Dasypodidae), Pilosa (Bradypodidae) and Rodentia (Erethizontidae). In contrast, immature stages infest mainly Passeriformes birds and can also occasionally be found on the above-mentioned mammal orders (Guglielmone et al., 2014; Nava et al., 2017).

There are several reports of this tick species, its morphology and distribution in Colombia. It was first recorded by Osorno-Mesa (1940), then by Luque Forero (1948), and more recently by Benavides-Montaño et al. (2018) in the departments of Meta, Tolima and Valle del Cauca, respectively. This paper reports for the first time, the presence of this tick species infesting collared anteaters (Tamandua tetradactyla) at different sites in the departments of Tolima and Cundinamarca, and identifies it by taxonomic, morphometric and molecular methods.

\section{Material and Methods}

Tick specimens were collected from two collared anteaters (Tamandua tetradactyla) in two municipalities, Melgar (coordinates: $4^{\circ} 12^{\prime} 42.9^{\prime \prime} \mathrm{N}, 74^{\circ} 40^{\prime} 40.6^{\prime \prime} \mathrm{W}$ ) and Arbeláez (coordinates: $4^{\circ} 16^{\prime} 28.7^{\prime \prime} \mathrm{N}, 7^{\circ} 25^{\prime} 22.0^{\prime \prime} \mathrm{W}$ ), in the Andean region near the border between the departments of Cundinamarca and Tolima in August 2017 and August 2018, respectively. The anteater from Melgar was found dead on a main road and the one from Arbeláez was delivered to the Laboratory of Veterinary Pathology for necropsy (Facultad de Medicina Veterinaria y de Zootecnia, Universidad Nacional de Colombia, Bogotá D.C.).

Ticks were stored in absolute ethanol and taken to the Veterinary Parasitology Laboratory of the Facultad de Medicina Veterinaria y de Zootecnia, Universidad Nacional de Colombia, Bogotá D.C., where they underwent taxonomic identification using current morphological keys (Barros-Battesti et al., 2006; López, 2017) under a light stereomicroscope (Olympus, Model: SZ2-ILST). In addition, nonengorged adult ticks from both populations were examined to record different morphometric variables, as described elsewhere for other Amblyomma species (Nava et al., 2014). Two males and two females from each site and host, were examined under a scanning electron microscope (SEM), after undergoing previous preparation protocols (Durden et al., 2018; Abdel-Shafy et al., 2019) for microscopic observation (Quorum, Model: Q150R ES).

Male and female specimens were deposited at the Veterinary Parasitology Collection-CPVUN (Facultad de Medicina Veterinaria y de Zootecnia, Universidad Nacional de Colombia, Bogotá D.C.), identified with batch numbers CPV-UN (A14) and CPV-UN (A15).

Finally, DNA from four males and four females was extracted individually for molecular identification, using a commercial kit (DNeasy ${ }^{\circledR}$ Blood \& Tissue Kit, Qiagen), as recommended by the manufacturer. Further, DNA templates were used for conventional PCR amplification of fragments of the genes $16 \mathrm{~S} \mathrm{rDNA}(\sim 460 \mathrm{bp})$, Cytochrome Oxidase C Subunit I-COI ( $700 \mathrm{bp}$ ) and the second internal transcribed spacer-ITS2 ( 1000 bp), using previously described primers and protocols (Folmer et al., 1994; Mangold et al., 1998; McLain et al., 1995; Zahler et al., 1995). PCR products were further purified using a commercial kit (Wizard ${ }^{\circledR}$ SV Gel and PCR Clean-Up System Kit, Promega) to perform automated Sanger sequencing (Genetic Analyzer ABI 3500) with the respective primers on both strands. Electropherograms were edited using UniproUGENE 1.32 software (Okonechnikov et al., 2012) to obtain consensus sequences. Additional sequences retrieved from GenBank (Federhen, 2012) were then added and multiple alignments constructed using the ClustalW algorithm (Thompson et al., 1997). Phylogenetic trees were calculated using MEGA 7.0 software (Kumar et al., 2016). These trees were built through a neighbor-joining method based on the Tamura genetic distance model (Tamura \& Nei, 1993), using 1000 replicates to estimate bootstrap values.

\section{Results}

A total of 134 adult ticks (104 males and 30 females) were identified as Amblyomma nodosum based on morphological and morphometric characteristics. Males present the following morphological characteristics: Dorsal - oval idiosome; rounded scapulae; short and deep cervical comma-shaped grooves; marginal groove absent; flat eyes; ornamented scutum with a "J"-shaped spot on both anterolateral sides, narrow spots at the posterior margin, small spots in the mid-lateral region and multiple punctuations distributed uniformly; festoons broader than long without tubercles; subrectangular basis capituli; prominent rounded cornua and a posterodorsal projection in palpi article II. Ventral - palpi article I with a short posterolateral projection; hypostome spatulate with 3/3 dentition 
in 6-7 rows; apex with corona of fine denticles; "U"-shaped genital aperture between coxae II and III; coxae I with two broad, triangular and blunt-pointed spurs, subequal in size; short spur in coxae II-IV; trochanters with no spurs; comma-shaped spiracular plate (Figure 1D-F). Females, in addition to these characteristics, present: Dorsal - complete marginal groove delimiting all festoons; ornamented scutum with a Y-shaped spot on both anterolateral sides; evident subtriangular basis capituli and short rounded cornua. Ventral - "V"-shaped genital aperture between coxae II and III; coxae I with two spurs, equal in size (Figure 1A- C). Morphometric variables recorded are summarized in the Table 1 and compared with previously measures registered by Serra-Freire et al. (1993), for idiosome length and breadth in both males and females.

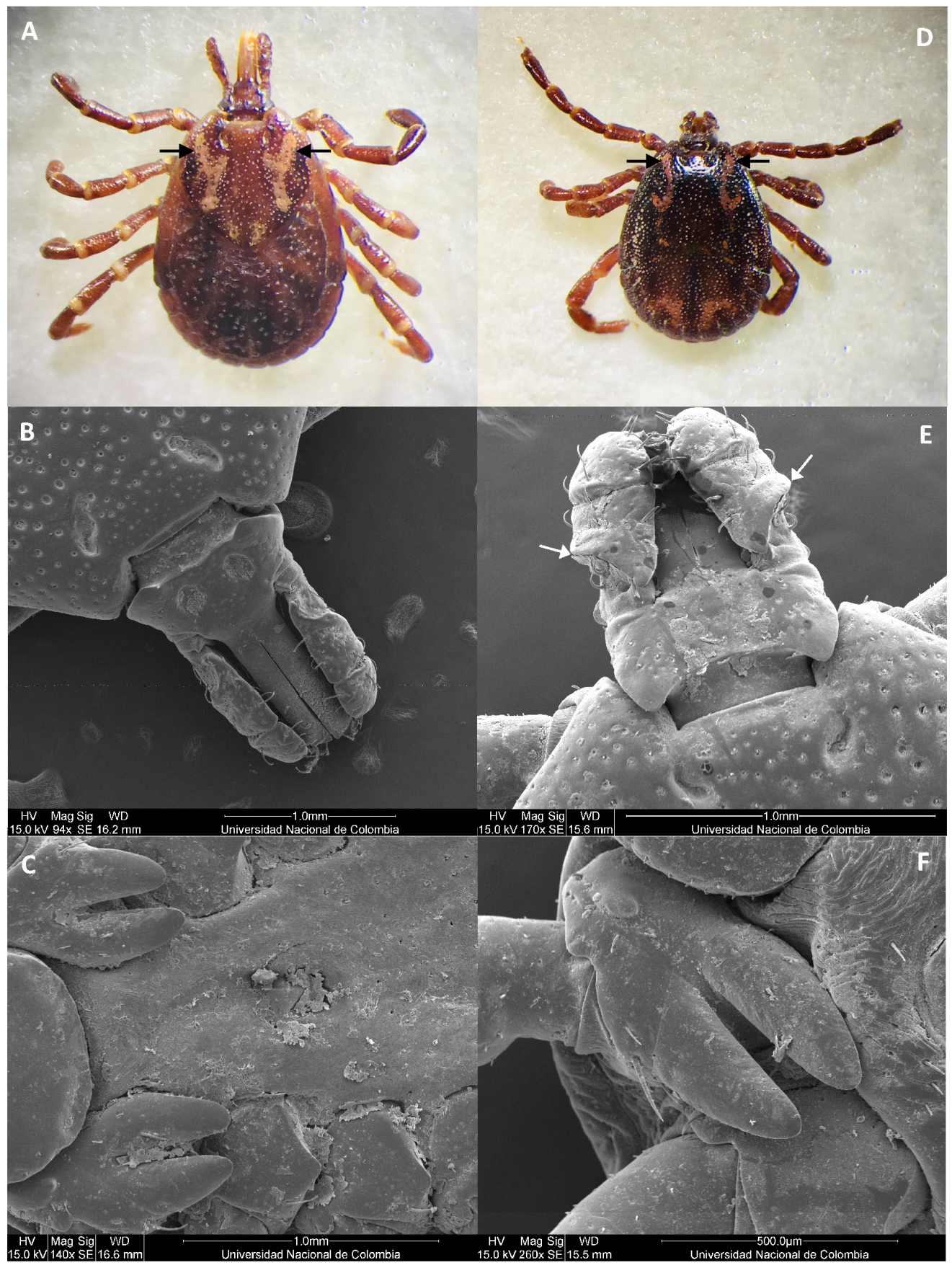

Figure 1. Morphological characteristics of adult specimens of Amblyomma nodosum collected on collared anteaters (Tamandua tetradactyla) from Melgar (Tolima) and Arbeláez (Cundinamarca) in August 2017 and August 2018. (A) Female, dorsal view. Arrows indicating the Y-shaped spot on the scutum (stereomicroscopic image, 1.25X); (B) Female, dorsal view showing capitulum and scutum anterior portion (SEM image); (C) Female, ventral view showing spurs at coxae I (SEM); (D) Male, dorsal view. Arrows indicating the J-shaped spot on the scutum (stereomicroscopic image, 1.25X); (E) Male, dorsal view. Arrows indicating posterodorsal projection in palpi article II (SEM); (F) Male, ventral view showing spurs at coxa I (SEM). 
Table 1. Mean morphologic variables registered in Amblyomma nodosum adult specimens collected from collared anteaters (Tamandua tetradactyla) from Melgar (Tolima) and Arbeláez (Cundinamarca) in August 2017 and August 2018*.

\begin{tabular}{|c|c|c|c|c|}
\hline Morphologic variable & \multicolumn{2}{|c|}{ Males } & \multicolumn{2}{|c|}{ Females } \\
\hline Total length & $5.1 \pm 0.36[4.4-5.6]$ & & $6.5 \pm 0.49[5.7-7.2]$ & \\
\hline Idiosome length & $4.3 \pm 0.33[3.9-4.8]$ & $3.0-4.5^{\S}$ & $5.2 \pm 0.72[4.4-6.7]$ & $4.8-5.5^{\S}$ \\
\hline Idiosome breadth & $3.2 \pm 0.18[2.9-3.5]$ & $2.5-3.8$ & $3.8 \pm 0.56[3.0-4.8]$ & 3.5-3.9 \\
\hline \multicolumn{5}{|l|}{ Dorsal view } \\
\hline Palpi-cornua length & $0.8 \pm 0.04[0.7-0.8]$ & & $1.3 \pm 0.13[1.1-1.4]$ & \\
\hline Basis capituli length & $0.3 \pm 0.03[0.2-0.3]$ & & $0.5 \pm 0.04[0.4-0.5]$ & \\
\hline Basis capituli breadth & $0.6 \pm 0.04[0.6-0.7]$ & & $0.9 \pm 0.11[0.8-1.1]$ & \\
\hline Scutum length & - & & $2.4 \pm 0.11[2.2-2.5]$ & \\
\hline Scutum width & - & & $2.3 \pm 0.61[1.0-2.9]$ & \\
\hline Scutum posterior length ${ }^{\dagger}$ & - & & $1.3 \pm 0.14[1.2-1.5]$ & \\
\hline Porose areas distance $e^{\ddagger}$ & - & & $0.1 \pm 0.02[0.1-0.2]$ & \\
\hline Porose areas length & - & & $0.2 \pm 0.03[0.1-0.2]$ & \\
\hline \multicolumn{5}{|l|}{ Ventral view } \\
\hline Basis capituli length & $0.4 \pm 0.05[0.3-0.5]$ & & $0.6 \pm 0.05[0.5-0.6]$ & \\
\hline Basis capituli breadth & $0.6 \pm 0.05[0.5-0.7]$ & & $0.8 \pm 0.03[0.7-0.8]$ & \\
\hline Palpi total length & $0.6 \pm 0.05[0.5-0.6]$ & & $0.8 \pm 0.04[0.7-0.8]$ & \\
\hline Segment I length & $0.2 \pm 0.02[0.2-0.2]$ & & $0.1 \pm 0.02[0.1-0.2]$ & \\
\hline Segment II length & $0.2 \pm 0.02[0.2-0.2]$ & & $0.4 \pm 0.02[0.4-0.4]$ & \\
\hline Segment III length & $0.2 \pm 0.04[0.1-0.2]$ & & $0.2 \pm 0.03[0.2-0.2]$ & \\
\hline Segment I width & $0.2 \pm 0.02[0.2-0.3]$ & & $0.2 \pm 0.01[0.1-0.2]$ & \\
\hline Segment II width & $0.2 \pm 0.01[0.2-0.2]$ & & $0.2 \pm 0.02[0.2-0.2]$ & \\
\hline Segment III width & $0.2 \pm 0.01[0.2-0.2]$ & & $0.2 \pm 0.02[0.1-0.2]$ & \\
\hline Hypostome length & $0.5 \pm 0.03[0.5-0.5]$ & & $0.7 \pm 0.05[0.7-0.8]$ & \\
\hline Hypostome width & $0.2 \pm 0.02[0.2-0.3]$ & & $0.2 \pm 0.03[0.2-0.3]$ & \\
\hline Tarsi I length & $0.6 \pm 0.04[0.6-0.7]$ & & $0.7 \pm 0.10[0.5-0.8]$ & \\
\hline Tarsi I width & $0.3 \pm 0.04[0.3-0.4]$ & & $0.3 \pm 0.04[0.2-0.3]$ & \\
\hline Spiracular plate length & $0.5 \pm 0.03[0.5-0.6]$ & & $0.5 \pm 0.07[0.4-0.6]$ & \\
\hline Spiracular plate width & $0.2 \pm 0.05[0.2-0.3]$ & & $0.5 \pm 0.10[0.3-0.6]$ & \\
\hline
\end{tabular}

*Data are shown as mean \pm standard deviation [range] in millimeters $(\mathrm{mm})$; †Length from eye level to posterior margin; $\ddagger$ Distance between porose areas; § Reference values obtained from Serra-Freire et al. (1993). For females data corresponds to unengorged ("neogina") individuals and for males corresponds to unengorged ("neandro") and fed individuals ("gonandro").

Molecular sequences were obtained for all the amplified genes (i.e.16S rDNA, COI and ITS2). A BLAST analysis of sequences available in the GenBank showed $99.4 \%$ and $99.8 \%$ similarity with deposited $A$. nodosum sequences for the 16S rDNA and COI genes, respectively. The highest similarity (99.5\%) for the ITS2 gene was with Amblyomma aureolatum, considering that no A. nodosum sequence for this gene is currently available in the database.

Phylogenetic trees were constructed for $16 \mathrm{~S}$ rDNA and COI genes (Figures 2 and 3). In the former, sequences obtained from samples 7 and 25 clustered with other A. nodosum deposited sequences from Brazil (GenBank 


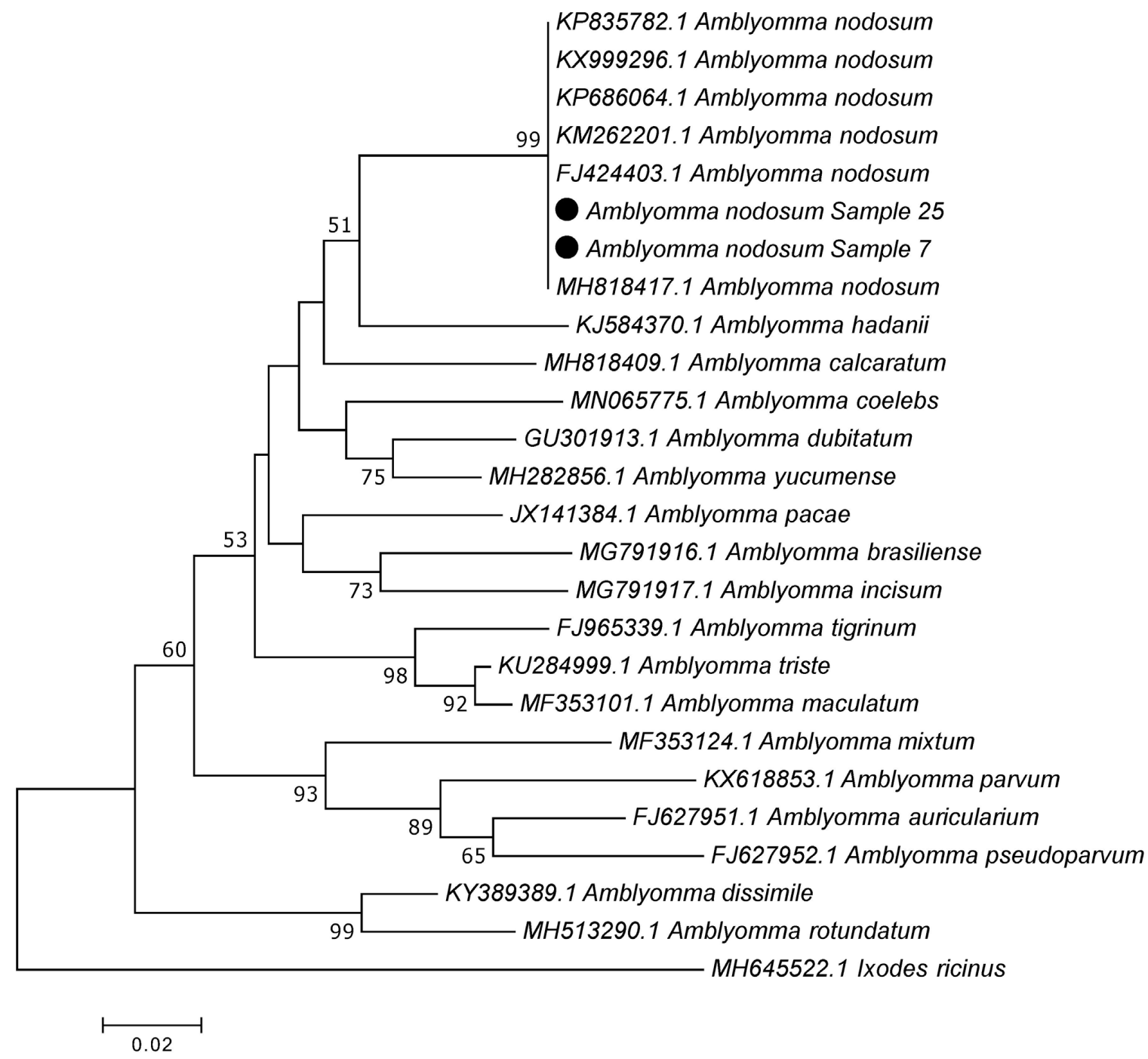

Figure 2. 16S rDNA gene phylogenetic tree inferred by the neighbor-joining method using Tamura-Nei computation for evolutionary distances. Black dots indicate sequences included for analysis. GenBank accession numbers are indicated for each sequence.

accession numbers: KX999296.1, KP686064.1, KM262201.1 and FJ424403.1), Honduras (KP835782.1) and Panama $(\mathrm{MH818417.1})$ (bootstrap value $=99.0 \%)($ Figure 2). Similarly, the tree constructed for the COI gene showed samples 5 and 8 clustering with A. nodosum deposited sequences from Panama (KF200131.1 KF200111.1) close to other sequences from Brazil (KY660045.1) and Panama (KF200138.1) (bootstrap value $=86.0 \%$ ) (Figure 3). No phylogenetic tree was constructed for the ITS2 gene due to the absence of deposited $A$. nodosum sequences in the GenBank database. A sequence for each gene was deposited in the GenBank under the following accession numbers: MN657253, MN652639, and MN652638.

\section{Discussion}

This is the first study in the pertinent literature reporting the presence of adult $A$. nodosum ticks on $T$. tetradactyla from Melgar (department of Tolima) and Arbeláez (department of Cundinamarca) identified by morphological, morphometric and molecular methods. Previous records in Colombia pertained to specimens collected during the first half of the $20^{\text {th }}$ century from collared anteaters, either females collected in Restrepo (Meta) (Osorno-Mesa, 1940) or males collected in Lérida (Tolima) (Luque Forero, 1948). After a lengthy hiatus in published records, Benavides-Montaño et al. (2018) collected adult A. nodosum specimens (58 males and 14 females) from the same host in Yotoco (department of Valle del Cauca). 


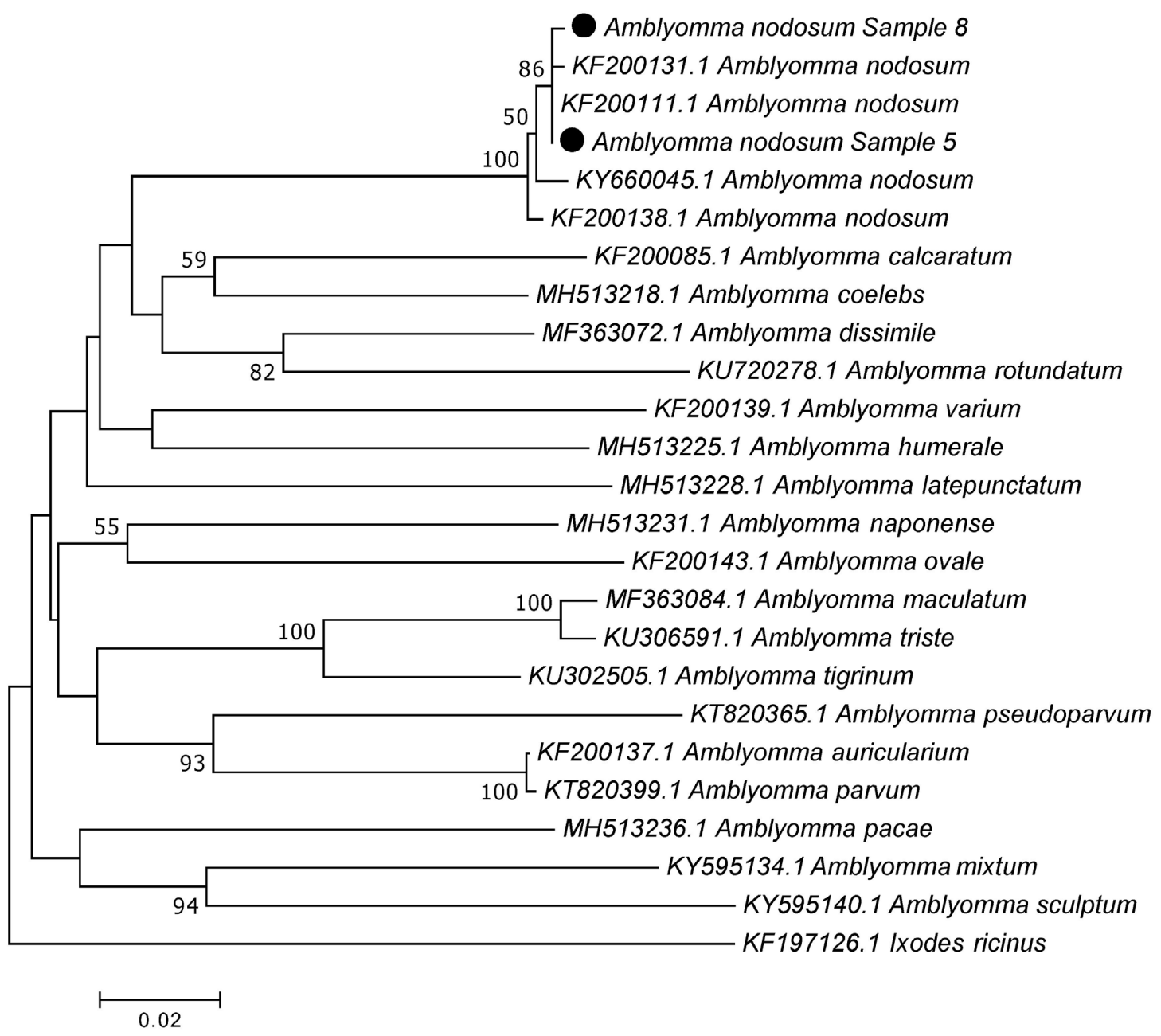

Figure 3. Cytochrome Oxidase subunit I (COI) gene phylogenetic tree inferred by the neighbor-joining method, using Tamura-Nei computation for evolutionary distances. Black dots indicate sequences included for analysis. GenBank accession numbers are indicated for each sequence.

Morphometric variables registered were compared with previous data published by Serra-Freire et al. (1993). In this study, authors measured 165 adults of $A$. nodosum (i.e. 130 males and 35 females) collected on five T. tetradactyla from Rio de Janeiro State. As presented in the Table 1, idiosome length and breadth values are comparable and fall within the range obtained in this study.

Anteaters of the family Myrmecophagidae, such as Myrmecophaga tridactyla, Tamandua mexicana and T. tetradactyla, are widely distributed, from Mexico to northern Argentina. In Colombia, these anteater species are found in almost all biogeographic regions (i.e., Orinoco, Pacific, Caribbean, Andean and Amazon regions), from sea level to 2,000 meters above sea level (1,500 meters in the case of $T$. mexicana), in dry and humid tropical and subtropical grasslands and shrublands, as well as in mangroves, in different states of anthropic intervention (Navarrete \& Ortega, 2011; Rojano et al., 2014). In this study, although adult tick specimens were collected from collared anteaters in the departments of Cundinamarca and Tolima in the Andean region, previous reports have included the Orinoco (Osorno-Mesa, 1940) and Pacific (Benavides-Montaño et al., 2018) regions; hence, a wider geographic dispersion is expected as a function of the aforementioned anteater distribution. Moreover, immature stages of $A$. nodosum (larvae and nymphs) have been found on 16 bird species (15 Passeriformes and one Coraciiformes) in Brazil (Ogrzewalska et al., 2009), reinforcing the plausibility of widespread dispersion.

There is increasing concern about the relevance of ticks and tick-borne diseases according to the One Health approach (Dantas-Torres et al., 2012). Studying tick species and their related microorganisms in wildlife could provide useful knowledge for application to environmental, animal and human health, through convergent, integrated and multidisciplinary approaches. Previous molecular studies have detected Rickettsia species such as Rickettsia bellii and Rickettsia parkeri strain NOD in A. nodosum ticks collected from birds (Lugarini et al., 2015; 
Ogrzewalska et al., 2009) and from T. tetradactyla (Almeida et al., 2013; Moerbeck et al., 2018; Szabó et al., 2019; Witter et al., 2016) in Brazil. Although R. bellii is considered nonpathogenic and the pathogenic role of R. parkeri strain NOD is unknown, one cannot ignore the relevance of the former in the interaction with other Rickettsia species (Krawczak et al., 2018), and the pathogenic potential of the latter due to its phylogenetic relationship with other R. parkeri pathogenic strains (Nieri-Bastos et al., 2018). Further studies involving microorganisms associated with $A$. nodosum in Colombia are therefore needed.

In this paper we report the presence of $A$. nodosum ticks on $T$. tetradactyla in two new locations in Colombia, thus expanding the current records and describing morphological and morphometric characteristics, and also providing phylogenetic information about three different gene fragments.

\section{Acknowledgements}

This work received financial support from the Universidad Nacional de Colombia (grant $n^{\circ} 41525$ ). We must acknowledge DVM Jonathan Arias, and the Unidad de Rescate y Rehabilitación de Animales Silvestres (URRAS) for his help in sample acquirement, and the staff from the Fundación Instituto de Inmunología de Colombia (FIDIC)'s Molecular Biology and Immunology Department for their help with molecular techniques.

\section{References}

Abdel-Shafy S, Ghazy AA, Shaapan RM. Applications of electron microscopy in ticks: description, detection of pathogens, and control. Comp Clin Pathol 2019; 28(3): 585-592. http://dx.doi.org/10.1007/s00580-018-2786-2.

Almeida RF, Garcia MV, Cunha RC, Matias J, Labruna MB, Andreotti R. The first report of Rickettsia spp. in Amblyomma nodosum in the State of Mato Grosso do Sul, Brazil. Ticks Tick Borne Dis 2013; 4(1-2): 156-159. http://dx.doi.org/10.1016/j.ttbdis.2012.08.002. PMid:23084365.

Barros-Battesti DM, Arzua M, Bechara GH. Carrapatos de importância médico-veterinária da região neotropical um guia ilustrado para identificação de espécies. São Paulo: Instituto Butantan; 2006.

Benavides-Montaño JA, Jaramillo-Cruz CA, Mesa-Cobo NC. Garrapatas Ixodidae (Acari) en el Valle del Cauca, Colombia. Bol Cient Mus Hist Nat 2018; 22(1): 131-150. http://dx.doi.org/10.17151/bccm.2018.22.1.12.

Dantas-Torres F, Chomel BB, Otranto D. Ticks and tick-borne diseases: a One Health perspective. Trends Parasitol 2012; 28(10): 437-446. http://dx.doi.org/10.1016/j.pt.2012.07.003. PMid:22902521.

Durden LA, Gerlach RF, Beckmen KB, Greiman SE. Hyperparasitism and non-nidicolous mating by male Ixodes angustus ticks (Acari: ixodidae). J Med Entomol 2018; 55(3): 766-768. http://dx.doi.org/10.1093/jme/tjy012. PMid:29471532.

Federhen S. The NCBI taxonomy database. Nucleic Acids Res 2012; 40(D1): D136-D143. http://dx.doi.org/10.1093/nar/gkr1178. PMid:22139910.

Folmer O, Black M, Hoeh W, Lutz R, Vrijenhoek R. DNA primers for amplification of mitochondrial cytochrome c oxidase subunit I from diverse metazoan invertebrates. Mol Mar Biol Biotechnol 1994; 3(5): 294-299. PMid:7881515.

Guglielmone AA, Robbins RG, Apanaskevich DA, Petney T, Estrada-Peña A, Horak IG. The hard ticks of the world (Acari: Ixodida: Ixodidae). Dordrecht: Springer Science; 2014. http://dx.doi.org/10.1007/978-94-007-7497-1.

Krawczak FS, Labruna MB, Hecht JA, Paddock CD, Karpathy SE. Genotypic characterization of Rickettsia bellii reveals distinct lineages in the United States and South America. BioMed Res Int 2018; 2018: 8505483. http://dx.doi.org/10.1155/2018/8505483. PMid:29850579.

Kumar S, Stecher G, Tamura K. MEGA7: Molecular Evolutionary Genetics Analysis version 7.0 for bigger datasets. Mol Biol Evol 2016; 33(7): 1870-1874. http://dx.doi.org/10.1093/molbev/msw054. PMid:27004904.

López G. Garrapatas (Acari: Ixodidae y Argasidae) de importancia médica y veterinararia, procedentes de Norte, Centro y Suramérica. Medellín: Editorial CES; 2017

Lugarini C, Martins TF, Ogrzewalska M, de Vasconcelos NC, Ellis VA, de Oliveira JB, et al. Rickettsial agents in avian ixodid ticks in northeast Brazil. Ticks Tick Borne Dis 2015; 6(3): 364-375. http://dx.doi.org/10.1016/j.ttbdis.2015.02.011. PMid:25800099.

Luque Forero G. Amblyomma nodosum en Tamandua tetradactyla. Rev Med Vet Zoot 1948; 17(97): 119-120.

Mangold AJ, Bargues MD, Mas-Coma S. Mitochondrial 16S rDNA sequences and phylogenetic relationships of species of Rhipicephalus and other tick genera among Metastriata (Acari: ixodidae). Parasitol Res 1998; 84(6): 478-484. http://dx.doi. org/10.1007/s004360050433. PMid:9660138. 
McLain DK, Wesson DM, Collins FH, Oliver JH Jr. Evolution of the rDNA spacer, ITS 2, in the ticks Ixodes scapularis and I. pacificus (Acari: ixodidae). Heredity 1995; 75(3): 303-319. http://dx.doi.org/10.1038/hdy.1995.139. PMid:7558890.

Moerbeck L, Vizzoni VF, Oliveira SV, Cavalcante R, Coelho GCB, Duarte NFH, et al. Rickettsia sp. strain NOD infecting ticks (Amblyomma nodosum) in an endemic area of spotted fever in Brazil.J Wildl Dis 2018; 54(2): 406-409. http://dx.doi.org/10.7589/201706-137. PMid:29261444.

Nava S, Beati L, Labruna MB, Caceres AG, Mangold AJ, Guglielmone AA. Reassessment of the taxonomic status of Amblyomma cajennense (Fabricius, 1787) with the description of three new species, Amblyomma tonelliae n. sp., Amblyomma interandinum n. sp. and Amblyomma patinoi n. sp., and reinstatement of Amblyomma mixtum Koch, 1884, and Amblyomma sculptum Berlese, 1888 (Ixodida: ixodidae). Ticks Tick Borne Dis 2014; 5(3): 252-276. http://dx.doi.org/10.1016/j.ttbdis.2013.11.004. PMid:24556273.

Nava S, Venzal JM, Acuña DG, Martins TF, Guglielmone AA. Ticks of the Southern Cone of America: diagnosis, distribution, and hosts with taxonomy, ecology and sanitary importance. Cambridge: Academic Press; 2017.

Navarrete D, Ortega J. Tamandua mexicana (Pilosa: myrmecophagidae). Mammal Spec 2011; 43(874): 56-63. http://dx.doi. org/10.1644/874.1.

Nieri-Bastos FA, Marcili A, De Sousa R, Paddock CD, Labruna MB. Phylogenetic evidence for the existence of multiple strains of Rickettsia parkeri in the New World. Appl Environ Microbio/ 2018; 84(8): e02872-17. http://dx.doi.org/10.1128/AEM.02872-17. PMid:29439989.

Ogrzewalska M, Pacheco RC, Uezu A, Richtzenhain LJ, Ferreira F, Labruna MB. Rickettsial infection in Amblyomma nodosum ticks (Acari: Ixodidae) from Brazil. Ann Trop Med Parasitol 2009; 103(5): 413-425. http://dx.doi.org/10.1179/136485909X451744. PMid:19583912.

Okonechnikov K, Golosova O, Fursov M. Unipro UGENE: a unified bioinformatics toolkit. Bioinformatics 2012; 28(8): $1166-1167$. http://dx.doi.org/10.1093/bioinformatics/bts091. PMid:22368248.

Osorno-Mesa E. Las garrapatas de la República de Colombia. Rev Acad Colomb Cienc Exactas Fis Nat [online] 1940; [cited 2020 May 19];4(13): 6-24 . Available from: http://www.accefyn.com/revista/Vol_4/No13/Las_garrapatas_dla_republica_de_colombia.pdf

Rojano C, Miranda L, Ávila R. Manual de rehabilitación de hormigueros de Colombia. El Yopal (Casanare): Fundación Cunaguaro, Geopark Colombia S.A.S.; 2014.

Serra-Freire NM, Peixoto BTM, Oliveira VL, Teixeira RH. Amblyomma nodosum Neumann, 1899: contribuição ao estudo morfológico de machos e fêmeas. Rev Bras Parasitol Vet 1993; 2(2): 105-108.

Szabó MPJ, Pascoal JO, Martins MM, Ramos VDN, Osava CF, Santos ALQ, et al. Ticks and Rickettsia on anteaters from Southeast and Central-West Brazil. Ticks Tick Borne Dis 2019; 10(3): 540-545. http://dx.doi.org/10.1016/j.ttbdis.2019.01.008. PMid:30709660.

Tamura K, Nei M. Estimation of the number of nucleotide substitutions in the control region of mitochondrial DNA in humans and chimpanzees. Mol Biol Evol 1993; 10(3): 512-526. http://dx.doi.org/10.1093/oxfordjournals.molbev.a040023. PMid:8336541.

Thompson JD, Gibson TJ, Plewniak F, Jeanmougin F, Higgins DG. The CLUSTAL_X windows interface: flexible strategies for multiple sequence alignment aided by quality analysis tools. Nucleic Acids Res 1997; 25(24): 4876-4882. http://dx.doi.org/10.1093/ nar/25.24.4876. PMid:9396791.

Witter R, Martins TF, Campos AK, Melo AL, Correa SH, Morgado TO, et al. Rickettsial infection in ticks (Acari: Ixodidae) of wild animals in midwestern Brazil. Ticks Tick Borne Dis 2016; 7(3): 415-423. http://dx.doi.org/10.1016/j.ttbdis.2015.12.019. PMid:26775021.

Zahler M, Gothe R, Rinder H. Genetic evidence against a morphologically suggestive conspecificity of Dermacentor reticulatus and D. marginatus (Acari: ixodidae). Int J Parasitol 1995; 25(12): 1413-1419. http://dx.doi.org/10.1016/0020-7519(95)00081-X. PMid:8719952. 